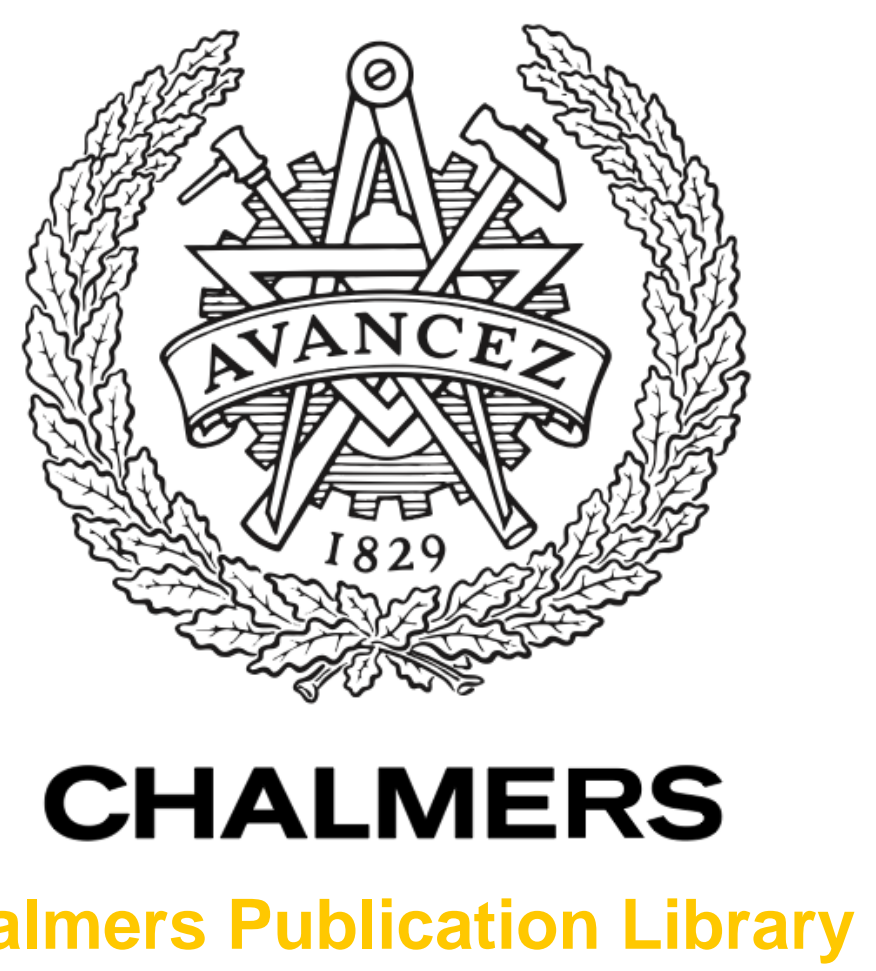

\title{
Greenhouse gas emissions and subjective well-being: An analysis of Swedish households
}

This document has been downloaded from Chalmers Publication Library (CPL). It is the author's version of a work that was accepted for publication in:

Ecological Economics (ISSN: 0921-8009)

Citation for the published paper:

Andersson, D. ; Nässén, J. ; Larsson, J. (2014) "Greenhouse gas emissions and subjective well-being: An analysis of Swedish households". Ecological Economics, vol. 102 pp. 75-82.

Downloaded from: http://publications.lib.chalmers.se/publication/199917

Notice: Changes introduced as a result of publishing processes such as copy-editing and formatting may not be reflected in this document. For a definitive version of this work, please refer to the published source. Please note that access to the published version might require a subscription. 


\section{Greenhouse gas emissions and subjective well-being: An analysis of Swedish households}

\section{Abstract}

In the contemporary discussion on society's transformation towards long-term climate targets, it is often implicitly assumed that behavioral changes, unlike technological changes, would lead to reductions in human well-being. However, this assumption has been questioned by researchers, who instead argue that people may live better lives by consuming less and reduce their environmental impact in the process. In this study we explore the relationship between greenhouse gas emissions and subjective well-being, using a sample of 1,000 Swedish respondents.

Our results show that there is no strong link between an individual's emissions and subjective well-being. We also analyze the relationship between specific emissionintensive activities and subjective well-being and find that none of the activities examined correlates with subjective well-being. Finally, we explore a hypothesis put forward in the literature, suggesting that a poor work-life balance, long commuting distances, and materialistic values may decrease individuals' subjective well-being and increase greenhouse gas emissions. Our results indicate that materialistic values do correlate with lower levels of well-being and to some extent also with higher greenhouse gas emissions.

Keywords: subjective well-being, household greenhouse gas emissions, double dividends, materialistic values 


\section{Introduction}

The European Union has adopted a long-term climate target to limit global warming to two degrees Celsius above pre-industrial levels (European Council, 2005). In order to have at least a likely chance of reaching this target, global carbon dioxide emissions would need to be halved between the base year of 1990 and 2050 and approach zero emissions by the end of the century (Rogelj et al. 2011; Meinshausen et al. 2009). Since reductions in developing countries are likely to take time, it is reasonable to assume that developed countries will need to decrease their greenhouse gas (GHG) emissions even more quickly. Assuming a so-called contraction and convergence model, where global per capita emissions are harmonized by 2050, this would imply Swedish reductions of at least 85 percent by 2050 ( $\AA$ kerman et al. 2007). According to official territorial accounting, Sweden reduced its GHG emissions by 20 percent between 1990 and 2012 (SEPA 2013a), while GDP increased by nearly 60 percent (Statistics Sweden, 2013). Seen from a consumption perspective, however, where emissions from imports are added and emissions from exports are subtracted, GHG emissions have instead increased by 15 percent between 1993 and 2010 (SEPA 2013b). Specific consumption trends that are not entirely covered in above accounts show that, since 1990, the consumption of red meat have increased by 54 percent (Swedish Department of Agriculture, 2013), and the number of passengers on international flights increased by 163 percent (Karyd, 2013). These trends in consumption indicate that a successful fulfillment of the two-degree climate target may require change that goes beyond eco-efficiency, by also considering lifestyle and consumption patterns. However, policies that enforce behavioral changes are not very popular among citizens (SOM 2012), probably because of perceived negative consequences for personal finances, convenience and, ultimately, quality of life.

The relationship between consumption and quality of life is contested. Fueled by findings in happiness research that show a diminishing returns for happiness with increased income (e.g. Kahneman, et al. 2006; Easterlin 2003; Inglehart et al. 2008), some scholars argue that people may live better lives by consuming less, reducing their environmental impact in the process (Zidansek 2007, see Jackson 2005 for a review of this discussion). This research often highlights ideas related to the concept of downshifting (a.k.a. "slow living,"), i.e., the shift away from a harried and material lifestyle to a lifestyle that puts more emphasis on leisure time and social relations (Schor 1998; Alexander and Ussher 2012; Markowitz and Bowerman 2012). 
Contemporary consumption research, however, emphasizes that consumption is important to one's identity, for example for maintaining social relations and expressing love (cf. Miller, 1998). In this view, activities and lifestyles with high GHG emissions may be important to us for many different reasons that do not have to relate to crude consumption.

The aim of this study is to analyze the relationship between the individual's subjective well-being and GHG emissions. Very few previous studies have explored this issue empirically, and to our knowledge none have done so in a sample with estimates of total GHG emissions (cars, air travel, electricity, heat, food and other consumption). Wilson et al. (2013) studied GHG emissions from residential energy use and road transport in Canada and found that higher emission levels in these domains were not connected to higher levels of SWB. Similar conclusions were drawn by Sekulova and van den Bergh (2013) who found that income reductions, which could possibly be seen as a proxy for emissions reductions, had only temporary effects on SWB. Lenzen and Cummins (2013) studied the role of different living conditions for both total carbon footprint and SWB in Australia, but due to data limitations they had to integrate results from two separate analyses of different survey databases. Other previous research analyzing the relationship between quality of life indicators and GHG emissions has mainly approached this issue by means of comparisons across nations (Zidansek 2007; Abdallah et al. 2009; Mazur 2011). Results from these studies suggest a positive but diminishing relationship between the GHG emissions of the population and their subjective well-being (SWB).

This paper addresses three specific research questions:

1. What is the general relationship between an individual's SWB and overall GHG emissions?

2. Do GHG-intensive activities and lifestyle choices (e.g., air-travel, leisuredriving - other than for work or commuting, red meat intensive diet, and large residences) affect an individual's SWB?

3. Are there behaviors or underlying factors that imply double dividends, i.e., that correlate with both low GHG emissions and high SWB?

By employing a survey questionnaire combined with registry-based data sources we estimate total GHG emissions for each individual. Through the survey we also collect information on SWB and other relevant explanatory variables. Section 2 includes a description of the mail survey, the variables used in the analysis, and a brief account 
of how GHG emissions were measured. The results are presented in section 3, and in section 4 we discuss our findings. Section 5 summarizes the main conclusions of our study.

\section{Method}

This section describes the mail survey and registry data sources used to estimate GHG emissions, SWB, and a set of explanatory variables.

\subsection{Survey}

The mail survey was sent out in May 2012, to a random sample of 2,500 individuals between 20 and 65 years of age, residing in the region Västra Götaland, in southwest Sweden. The population density of the region is 65 residents per $\mathrm{km}^{2}$, which is more than twice as high as for Sweden as a whole. Gothenburg, Sweden's second largest city, is the main center, with about one third of the region's 1.5 million residents.

The net response rate amounted to 40.1 percent, after two survey mailings, three postcard reminders, and one telephone reminder. Although this is a relatively high response rate compared to international levels, the fact that less than half of the sample population chose not to participate in the survey required a non-response rate analysis. We compared characteristics of the sample population to averages in the specified cohort in Västra Götaland and in Sweden as a whole (obtained from Statistics Sweden 2013) and found these differences: Women were more likely to answer the survey (55 percent of the respondents); individuals with higher incomes were also overrepresented in the sample; the mean income was 6 percent higher than the average in Västra Götaland and 4 percent higher than the national average. We also found an age bias as our respondents were on average four years older than the average citizen. Finally, there is a bias towards higher education in the survey sample, as 60 percent of the respondents have post-secondary education, compared to 39 percent of the general population in both Västra Götaland and Sweden as a whole. In most cases, these differences are small and illustrate that our sample is representative for the total population of Västra Götaland as well as Sweden as a whole. The exception is with respect to education, and this may be problematic since higher education could entail differences in other relevant factors as well.

We also controlled for the risk of a self-selection bias given the focus on environmental issues in the survey. The questionnaire included a question on 
environmental concern, identical to a question included in a broader survey conducted in the same year (SOM, 2012). Luckily, our respondents did not diverge from the general survey on this question.

\subsubsection{The Questionnaire}

The respondents were asked to answer a total of 47 questions covering different aspects of their everyday lives, including 12 questions meant to retrieve information necessary for the estimation of each individual's GHG emissions (as a complement to registry-based data) and 15 general questions on background characteristics. The questionnaire also included questions on time-use patterns, questions aimed at identifying pro-environmental norms/attitudes/behaviors, and so on. In order to evaluate the questions and scales used in the main survey, a small pilot survey was conducted in 2011, with answers from 87 respondents.

\subsection{Measuring Greenhouse gas emissions}

The method used to estimate household GHG emissions is summarized in Table 1 below. We include the three most important anthropogenic greenhouse gases: carbon dioxide $\left(\mathrm{CO}_{2}\right)$, methane $\left(\mathrm{CH}_{4}\right)$, and nitrous oxide $\left(\mathrm{N}_{2} \mathrm{O}\right)$, expressed as carbon dioxide equivalents $\left(\mathrm{CO}_{2} \mathrm{e}\right)$ based on their respective global warming potential (GWP) over 100 years. Emissions from residential energy use, private transport, and other nonfood consumption are attributed to the household as a whole and divided by the number of adults in each household. Remaining emissions that derive directly from the individual's consumption, i.e., public transport, air-travel, and food consumption, are then added to establish the total GHG emissions of the adult respondents. In all analyses, the GHG emissions are presented per adult. 
Table 1: Methods used to estimate GHG emissions from different consumption categories

\begin{tabular}{ll}
\hline Category & Data sources and assumptions \\
\hline Private car & The Swedish Road Registry (SRR) stores odometer readings from the two most recent \\
transport & $\begin{array}{l}\text { vehicle inspections together with other relevant data such as fuel type, fuel } \\
\text { consumption, } \mathrm{CO}_{2} \text { emissions, car make and model. New cars are not inspected during }\end{array}$ \\
& the first three years, and for these vehicles we relied on the respondents' stated annual \\
& driving distance in the questionnaire together with vehicle specific data from SRR. The \\
& fuel consumption stated in the SRR is based on the NEDC test-cycle scores in which all \\
& electric equipment is turned off and driving conditions are optimal. Fuel consumption \\
& during regular usage has been estimated to be 15-40\% higher than the NEDC scores \\
& (Patterson et al. 2011). We increased the SRR values by 20\% to take this into account.
\end{tabular}

Local public Respondents were asked about their weekly commuting choices and distance to work. transport Estimates of $\mathrm{CO}_{2}$ emission intensities from public transport were provided by the local public transport provider (Västtrafik) and amounted to $0.031 \mathrm{kgCO} 2 /$ passenger-km $\left(0.04 \mathrm{kgCO}_{2} /\right.$ passenger-km from bus travels and $0.02 \mathrm{kgCO} 2 /$ passenger- $\mathrm{km}$ for trams and commuter trains).

Air travel Respondents were asked about their air travel: the number of flights (for other than business reasons) to Nordic and European countries respectively in the past 2 years, and the number of inter-continental flights in the past 5 years. Average distances were calculated using the distance and frequency to different destinations from the main international airport in the region (Landvetter Airport). $\mathrm{CO}_{2} \mathrm{e}$ emissions estimates of average aircraft emissions per passenger-kilometer were collected from the Finish LIPASTO-calculation system (VTT, 2009). A conservative high-altitude factor of 1.7 was used to incorporate the full GWP effect of contrails and induced cloud formation from aviation (Azar and Johansson, 2012).

Electricity We received data on 200 respondents' annual electricity consumption directly from their utility companies. This information was then used together with explanatory data from the survey on self-stated electricity behavior, types of household appliances, type of residence and size, to construct a model $\left(\mathrm{R}^{2}=0.61\right)$ to estimate electricity consumption for the remaining households in the survey. We assume a EU electricity mix of $0.305 \mathrm{kgCO}_{2}$ e per kwh to reflect the conditions given by the EU-ETS cap-andtrade policy scheme where the total emissions are set by the issuing of emission permits at the political level. But from a physical perspective, the actual power system in Sweden is primarily interconnected with the neighboring Nordic countries.

Space and GHG emissions were calculated as the product of five factors (residential floor surface water heating area; energy performance; heating system efficiency; indoor temperature; emissions factor). For buildings included in the Energy Declarations registry, some of these factors could be collected directly from the registry ( $38 \%$ of the sample), while data from the questionnaire were used for the remaining households.

Food Measuring the emissions from all food products was not feasible, so we focused on red meat consumption, which accounts for a large share of emissions and much of the variation among individuals. Bryngelsson et al. (2013) estimated the average Swedish emissions from food consumption to $1,500 \mathrm{~kg} \mathrm{CO}_{2} \mathrm{e} / \mathrm{cap} / \mathrm{y}$, of which $800 \mathrm{~kg}$ originate from meat consumption. A multi-item question asking the respondents to assess the composition of their diets was used together with GHG emission estimates (Röös 2012) to calibrate the $800 \mathrm{~kg} \mathrm{CO}_{2} \mathrm{e}$ per capita. Emissions from other food types were assumed to be $700 \mathrm{~kg} \mathrm{CO}_{2}$ e per capita for all individuals in the sample.

Other Other consumption includes clothing, consumer electronics, entertainment, and so on.

consumption By using statistics from the Household Budget Surveys together with emissions data from the Swedish Environmental Accounts, we were able to construct a model $\left(\mathrm{R}^{2}=\right.$ 0.88 ) describing the relationship between expenditures on "other consumption" and the resulting GHG emissions. This model was then used together with estimates of each respondent's remaining consumption space derived from our survey data on income, savings, and other large budget posts. 


\subsection{Quality of life indicators - Subjective well-being}

In this study we have chosen to use subjective well-being (SWB) as an indicator of the respondent's quality of life. However, SWB is just one among several measures designed to capture what we mean by quality of life, including various forms of objective indicators, capabilities, and actualization of human potential. SWB is not the only component of a good life, but it is an important aspect, and it has gained widespread use in both research and applied welfare statistics.

SWB as defined by Diener et al. (1999) is an aggregate measure that combines an affective component (presence of positive or negative mood) and a cognitive component (self-rated life satisfaction). Research has shown that these two components are correlated to some extent (in this study, $0.77^{* *}$ ), but it is also possible to be in a positive mood while being simultaneously dissatisfied with one's life and to be satisfied with one's life while being in a negative mood. Hence, the hybrid (aggregated) approach to SWB seems reasonable, as it would be difficult to argue that a person has a high level of well-being while lacking either the affective or cognitive component (Brülde, 2007).

The two-item question used in this study is similar to that used in the World Values Survey (Inglehart et al. 2008). The affective component was measured by asking the respondent how he/she "feels in general" on a seven-point Likert scale, where 1 means "sad" and 7 means "happy." The cognitive evaluation instead asks the respondent "how satisfied are you on the whole with the life you live?" where the outermost alternatives were "not at all satisfied" and "very satisfied," respectively. The SWB indicator is the sum of these components with equal weighting, normalized on a $0-10$ scale.

\subsection{Explanatory variables}

The third aim of the study is to explore behaviors or underlying factors that may imply double dividends, i.e., factors that are positively correlated with SWB and negatively (or at least neutrally) correlated with GHG emissions. As mentioned in the introduction, previous research that has addressed lifestyle changes that would benefit both ecological sustainability and individual well-being has often highlighted ideas related to the concept of downshifting. The survey used in this study was designed to test some of these theories empirically. 


\subsubsection{Commuting}

Individuals who commute long distances by car can for obvious reasons be expected to have higher transportation GHG emissions. Irrespective of what mode of transport a person use, commuting also takes time from other social activities that are beneficial for our well-being (Dolan and White 2007) and has also been shown to correlate with health problems (Hansson 2011) and low levels of SWB (Stutzer and Frey 2008; Killingsworth and Gilbert 2010). However, Olsson et al. (2013) found that feelings during commutes are predominantly positive or neutral and speculate that the commuting offers buffer time between work and private spheres of life. Both commuting time and distance is important to the SWB and GHG emission dimensions respectively, and we measured both in the questionnaire by asking respondents to assess the time and distance to work and which mode of transport they used. Since respondents' time-estimates is a mean between different modes of transport and we are interested in car commuters, we chose to use commuting distance in the analysis as it is also an adequate proxy for commuting time.

\subsubsection{Work-life balance}

As pointed by for example Jackson (2009), reducing and sharing the work-time may imply potential double dividends by both reducing ecological impact and improving the quality of life. Paid work provides us with income that is used for consumption, which in turn generates GHG emissions (Knight et al. 2013; Nässén and Larsson, 2013), while long work hours are likely to infringe on leisure time with family and friends, a factor that has been shown to be an important determinant of an individual's SWB (Argyle 1999).

We asked respondents about their average work hours each week in order to see how this factor affects SWB and GHG. Following Larsson (2012), we also asked respondents two questions assessing their experience of time pressure. We first asked how frequently the respondent felt he/she "experienced discomfort in trying to keep up with everything that needs to be done," and then we asked how strong these feelings of discomfort are. The reason for the second question is that stress tolerance seems to vary among individuals and life situations. Parents, for example, tend to endure a hectic everyday life without experiencing strong feelings of discomfort. Cronbach's alpha for this combined measure was 0.81 . The scores on the respective answers were then added and normalized on a 0-10 scale. 


\subsubsection{Materialistic values}

People holding materialistic values, i.e., individuals concerned about the acquisition of material things, have been shown to have lower SWB than others (Ryan and Dziurawiec 2001; Williams et al. 2000). They also engage in relatively fewer environmentally friendly behaviors, like recycling, than others (Richins and Dawson 1992; Brown and Kasser 2005, Hurst et al. 2013), but to our knowledge no previous study has examined the connection between materialistic values and a reliable environmental measure such as GHG emissions.

In order to measure the level of materialistic values among the respondents, we used a translated version of the well-established Material Values Scale (MVS, Richins and Dawson 1992). Because of the space restrictions, we used the short-form that has been shown to have satisfactory psychometric properties (Richins, 2004). The shortform is made up of 9 statements answered on a 5-point Likert scale. We developed a translated version of the short form and verified it through an online pilot survey.

Two items were dropped from the MVS. The MVS is divided into three dimensions (Success, Centrality, and Happiness), and in our initial data analyses we discovered a significant negative correlation between household income and one of the questions used in the happiness dimension of the MVS form ("It sometimes bothers me quite a bit that I can't afford to buy all the things I'd like" Richins, 2004). It seems reasonable to assume that low-income households are more likely to respond affirmatively on this question for "legitimate" reasons, and this question-item was dropped from the scale. Another item lowered the internal consistency of the measure substantially, probably because of its reverse order formulation and was consequently dropped in the analysis ("I try to keep my life simple, as far as possessions are concerned"). The Cronbach's alpha for the remaining 7 items was 0.83 . These answers were then added and normalized on a $0-10$ scale.

\subsubsection{Other socio-economic variables included in the models}

In the survey we also asked respondents questions pertaining to other socio-economic conditions that have been shown to influence either GHG emissions or SWB. These variables are described below.

Variables likely to affect GHG: Household income and hence spending are strong determinants of GHG emissions (e.g., Lenzen et al, 2006; Kerkhof et al, 2009; Nässén 2014). A Swedish study shows that men cause more GHG emissions than women due 
to differences in travel behavior, and gender is therefore included in the analysis (SIKA 2007). Differences in age may also affect GHG emissions, because of differences in lifestyles, and so on, and we have therefore decided to include age as a control variable. Education has previously been shown to affect environmental attitudes; we therefore assumed that differences in education could spill over into environmentally relevant behaviors (Tjernström and Tietenberg 2008).

Variables likely to affect SWB: Working and studying have both been shown to affect SWB positively; having social relations with friends, family, or a partner also increases our well-being (Argyle 1999). Participating in sports or exercising is partially a social activity, but the physical experience itself also seems to increase SWB (Csikszentmihalyi 1992; Mutrie and Faulkner 2004). Being in good health is probably one of the most important factors influencing how we feel in general (Argyle 1999).

\section{Results}

This section includes the descriptive statistics, an analysis of the relationship between SWB and GHG, and a GHG/SWB matrix where hypothesized differences in certain parameters are described.

\subsection{Descriptive statistics}

Average annual GHG emissions per adult are 8.2 tons of $\mathrm{CO}_{2} \mathrm{e}$. As noted above, emissions per adult were estimated as the household's shared GHG emissions from residential energy, private car transport, and other shared (non-food) consumption divided by the number of adults in the household plus individual GHG emissions from public transport, air travel, and food consumption. When children are included in the denominator, the corresponding per capita estimate in our sample is 7.2 tons, which is lower than the 8 tons per capita estimated by the Swedish EPA (SEPA 2008). The difference is probably due to underreporting of own income due to forgotten incomes, which results in reduced emissions from other consumption. The difference is not very large, and for the purpose of our analysis we do not need a totally representative population. The mean SWB of 7.4 is in line with other studies of the Swedish population (Fors and Brülde, 2011). 
Table 2: Descriptive statistics for the variables used in the analysis

\begin{tabular}{|c|c|c|c|c|c|}
\hline & Mean & S.D. & Min & Max & $\mathrm{N}$ \\
\hline \multicolumn{6}{|l|}{ Dependent variables } \\
\hline GHG emissions (per year) & 8.2 & 3.18 & 1.9 & 22.8 & 983 \\
\hline SWB & 7.4 & 1.89 & 0 & 10 & 971 \\
\hline \multicolumn{6}{|l|}{ Determinants } \\
\hline Material values scale (MVS) & 2.5 & 1.84 & 0 & 10 & 958 \\
\hline Time pressure & 4.7 & 2.27 & 0 & 10 & 963 \\
\hline Work hours (per week) & 33.3 & 17.1 & 0 & 95 & 962 \\
\hline Commuting distance (kilometers, one way) & 18.2 & 25 & 0 & 290 & 822 \\
\hline \multicolumn{6}{|l|}{ Background variables } \\
\hline Education & 5 & 1.78 & 1 & 8 & 975 \\
\hline Gender (male) & 0.45 & 0.5 & 0 & 1 & 979 \\
\hline Age & 46 & 13 & 20 & 66 & 983 \\
\hline Children & 0.61 & 0.49 & 0 & 1 & 980 \\
\hline \multicolumn{6}{|l|}{ Variables known to affect $S W B$} \\
\hline Working or studying & 0.83 & 0.38 & 0 & 1 & 949 \\
\hline Net income per adult (in thousands SEK) & 204 & 80 & 0 & 946 & 970 \\
\hline Has partner & 0.77 & 0.42 & 0 & 1 & 977 \\
\hline Health & 5.4 & 1.31 & 1 & 7 & 975 \\
\hline Family time (hours per week) & 3.6 & 2.11 & 1 & 8 & 954 \\
\hline Social time (hours per week) & 2.7 & 1.38 & 1 & 8 & 963 \\
\hline Exercising (hours per week) & 3.6 & 1.99 & 1 & 8 & 973 \\
\hline \multicolumn{6}{|l|}{ GHG intensive activities } \\
\hline Size of residence $\left(\mathrm{m}^{2}\right)$ & 113 & 54.4 & 14 & 380 & 972 \\
\hline Non-work-related driving (km/year) & 4756 & 9951 & 0 & 82743 & 975 \\
\hline Air travel (flights/year) & 1.2 & 1.28 & 0 & 7 & 983 \\
\hline Red meat (share of meals per week) & 0.18 & 0.59 & 0 & 1 & 983 \\
\hline
\end{tabular}

3.2 The relationship between GHG emissions and subjective well-being

The main aim of this study is to learn more about the relationship between GHG emissions and SWB. Figure 1 below provides a visual representation of this relationship in our sample. The upper diagram shows the respondents sorted according to their GHG emissions and grouped into 10 decile groups. The emission level in the highest decile is 3.4 times that of the lowest. The lower diagram presents the corresponding SWB average for each of the ten groups. There is essentially no significant difference among the groups. One possible visual interpretation is that there is a weak positive correlation between GHG and SWB among the groups 1 to 7, and a weak negative correlation among the groups 7 to 10 . The comparatively low 
SWB of group 1 stands out, but as we will learn below, this can be traced to the relatively high levels of unemployment and long-term poor health in this group.

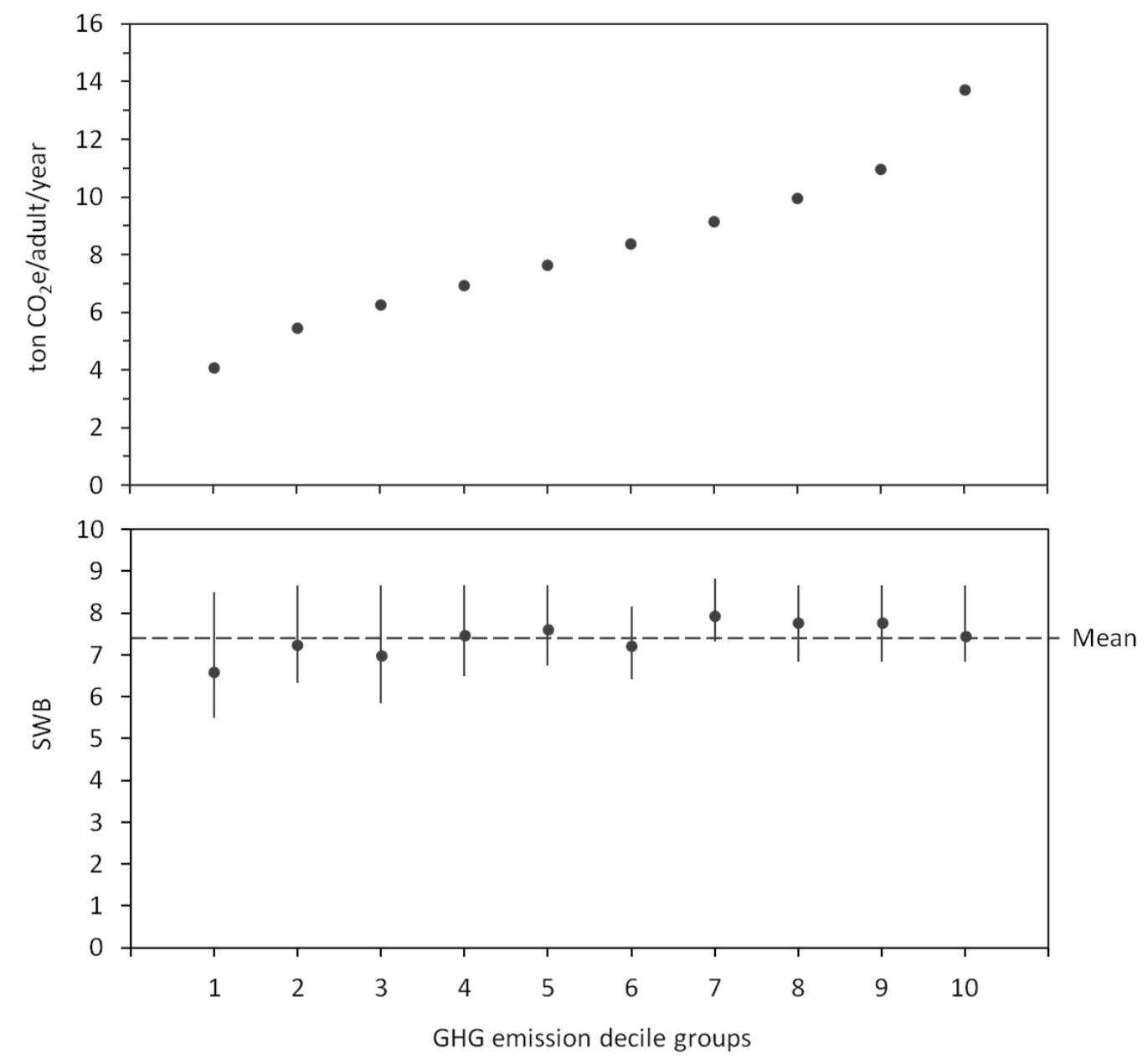

Figure 1: GHG emissions and SWB sorted by GHG emission decile groups.

The points in the upper diagram represent the average emission levels in ten decile groups (each group represents around 100 households). The lower diagram shows the corresponding average levels of subjective well-being in these decile groups. The vertical lines represent the inner quartile ranges.

Table 3 below presents a decomposed view of the respondents SWB and GHG emissions in a correlation matrix. GHG emissions from transportation (private and public), air travel, and other (non-food) consumption are found to have a weak positive correlation with SWB, while no significant correlation is found for residential energy and food consumption. Only small differences are found between the affective and the cognitive components of the SWB index. The three emission categories for which significant correlations with SWB are found are also the three categories with the strongest correlation with income.

When respondents who do not work or study are excluded from the sample, no correlation is found between SWB and GHG, and out of the GHG emission components only air travel is weakly correlated to the level of SWB. Hence the weak 
correlation between GHG and SWB found in the full sample appear to be associated with the third variable unemployment, which both correlates with low SWB and low consumption levels that in turn lead to low GHG emissions.

Table 3: Correlation matrix for SWB components and GHG emission components (ton $\mathrm{CO}_{2}$ eladult/year)

\begin{tabular}{|c|c|c|c|c|c|c|c|c|c|}
\hline & 1. & 2. & 3. & 4. & 5. & 6. & 7. & 8. & 9 \\
\hline 1. SWB Index & & & & & & & & & \\
\hline 2. Cognitive well-being & $.94^{* *}$ & & & & & & & & \\
\hline 3. Affective well-being & $.94^{* *}$ & $.77^{* *}$ & & & & & & & \\
\hline 4. Income & $.17^{* *}$ & $.15^{* *}$ & $.16^{* *}$ & & & & & & \\
\hline 5. Tot GHG & $.14^{* *}$ & $.14^{* *}$ & $.12^{* *}$ & $.53^{* *}$ & & & & & \\
\hline 6. Residential & - & - & - & $.19^{* *}$ & $.67^{* *}$ & & & & \\
\hline 7. Transport & $.11^{* *}$ & $.09^{* *}$ & $.12^{* *}$ & $.32^{* *}$ & $.66^{* *}$ & $.27^{* *}$ & & & \\
\hline 8. Air travel & $.13^{* *}$ & $.13^{* *}$ & $.10^{* *}$ & $.24^{* *}$ & $.45^{* *}$ & - & - & & \\
\hline 9. Food & - & $.07^{* *}$ & - & $.12^{* *}$ & $.17^{* *}$ & - & $.11^{* *}$ & $.06^{*}$ & \\
\hline 10. Other consumption & $.14^{* *}$ & $.13^{* *}$ & $.13^{* *}$ & $.55^{* *}$ & $.42^{* *}$ & $.08^{*}$ & $.15^{* *}$ & - & - \\
\hline
\end{tabular}

\subsection{Explaining SWB: Do GHG intensive activities play a role?}

The second aim of the study is to analyze if there exists specific GHG emission intensive activities that are positively related to SWB. The analysis above suggests that there is no strong overall relationship between GHG emissions and SWB, but since such a relationship would only be an indirect effect of consumption activities, we analyze these activities specifically. A standard OLS regression analysis is used and we construct three models that all include a set of control variables (education, gender, age, and having children) and a combination of variables known to affect SWB (described in section 2.4.4) and GHG emission intensive variables including: size of residence, driving other than for work or commute (total distance minus commuting distance), number of non-work trips by air, and share of red meat in diet. Net income per adult is not included in the analysis as we are primarily interested in the consumption activities and their relation to SWB. In order to test for possible effects of income we ran the models including net income per adult, only to find that this parameter was not significant in any of the models and did not affect the adjusted $\mathrm{R}^{2}$ relative to the models below.

Model 1 is the proposed "best fit" model; including variables that previous research has demonstrated affect SWB. Model 2 includes only the GHG emission intensive activities, and Model 3 includes both GHG intensive activities and variables known to affect SWB. The reason for providing all three models is that changes in beta values and explained variation $\left(\mathrm{R}^{2}\right.$ values) can be of interest to subsequent analysis. 
Table 4: OLS regressions describing Subjective well-being (Standardized beta values)

\begin{tabular}{|c|c|c|c|c|}
\hline Models & & Model 1 & Model 2 & Model 3 \\
\hline \multirow[t]{4}{*}{ Control variables } & Education & -0.007 & 0.040 & -0.001 \\
\hline & Gender & -0.026 & -0.001 & -0.032 \\
\hline & Age & $0.118 * * *$ & $0.094^{* *}$ & $0.109 * * *$ \\
\hline & Has children & 0.003 & -0.030 & -0.005 \\
\hline \multirow{7}{*}{$\begin{array}{l}\text { Variables known } \\
\text { to affect } S W B\end{array}$} & Working or studying & $0.130 * * *$ & - & $0.128 * * *$ \\
\hline & Partner & $0.136 * * *$ & - & $0.123 * * *$ \\
\hline & Health & $0.458 * * *$ & - & $0.455 * * *$ \\
\hline & Time pressure & $-0.149 * * *$ & - & $-0.152 * * *$ \\
\hline & Family time & $0.158 * * *$ & - & $0.158 * * *$ \\
\hline & Social activities & $0.138 * * *$ & - & $0.136 * * *$ \\
\hline & Exercising & -0.017 & - & -0.019 \\
\hline \multirow{4}{*}{$\begin{array}{l}\text { GHG intensive } \\
\text { activities }\end{array}$} & Size of residence $\left(\mathrm{m}^{2}\right)$ & - & $0.080 *$ & 0.039 \\
\hline & Non-work driving $(\mathrm{km} / \mathrm{y})$ & - & 0.050 & 0.003 \\
\hline & Air travel (flights/y) & - & $0.126 * * *$ & 0.024 \\
\hline & Red meat (meals $/ w)$ & - & 0.037 & 0.028 \\
\hline \multicolumn{2}{|l|}{$\bar{N}$} & 894 & 952 & 887 \\
\hline \multicolumn{2}{|l|}{$R^{2}$ adjusted } & 0.392 & 0.036 & 0.393 \\
\hline
\end{tabular}

Model 1 shows that among the control variables, age is positively correlated with SWB, and all of the variables previously known to affect SWB also prove to be significant, except for exercising. The model has a relatively high explanatory value (adjusted $\mathrm{R}^{2}=0.392$ ), especially since previous research indicates that personality traits determine a large part of a person's subjective well-being (see Steel et al. 2008 for a meta-review). Self-assessed health also explains about half of the variation in SWB in the model.

Model 2 includes only GHG emission intensive activities and control variables in the analysis. In this model, air travel and residence size are significantly correlated with $\mathrm{SWB}$, but the explanatory power of the model is very low (adjusted $\mathrm{R}^{2}=0.036$ ). This result is in line with some previous research (Brülde and Fors 2013; Nawijin and Peeters 2010).

Model 3 includes both GHG emission intensive activities and variables known to affect SWB and have roughly the same explanatory power as model 1 . Here, both air travel and size of residence become insignificant. Hence none of the GHG emission intensive activities analyzed here seem to have a direct relationship to SWB when other relevant variables are included in the analysis. 
However, a vacation abroad, for instance, may offer an opportunity for social activities such as spending time with friends and family; air travel may therefore be a vehicle for social activities that in turn increase SWB. In order to test this opportunity, we ran model 1 with air travel as the dependent variable. This analysis shows that individuals who engage more frequently in social activities or have a partner are more likely to travel, while having children greatly limit this propensity.

\subsection{Double dividends in the SWB-GHG relationship?}

In the previous sections we have showed that the total GHG emissions from households is only weakly connected to SWB and that GHG intensive activities are not related to SWB to any significant extent. However, behind these weak aggregated correlations there may exist factors that affect both GHG and SWB but in opposite directions. In this section we look at more specific values and lifestyle choices that could have a beneficial effect on SWB while reducing GHG emissions.

As discussed in section 2.4.1, previous research has shown that individuals who are relatively high in materialistic values generally fare lower in SWB and are more likely to adhere to a less environmental-friendly lifestyle (Richins and Dawson 1992; Brown and Kasser 2005). Also, individuals who prioritize work over leisure time have been hypothesized to have lower SWB and a higher environmental impact (Jackson 2009). We operationalize this by looking at differences in self-assessed time-pressure and respondents who state that they work overtime separately. We also analyze the effects of commuting, which has been hypothesized to increase GHG emissions and lower SWB.

In order to study the effects on both SWB and GHG emissions, we divide the samplepopulation into four sub-samples using median splits on SWB and GHG, respectively (see figure 2). In the following, differences between sub-sample 1 and 4 will be of special interest to our analysis, as differences in the variables above between these groups would indicate the existence of double dividends. 


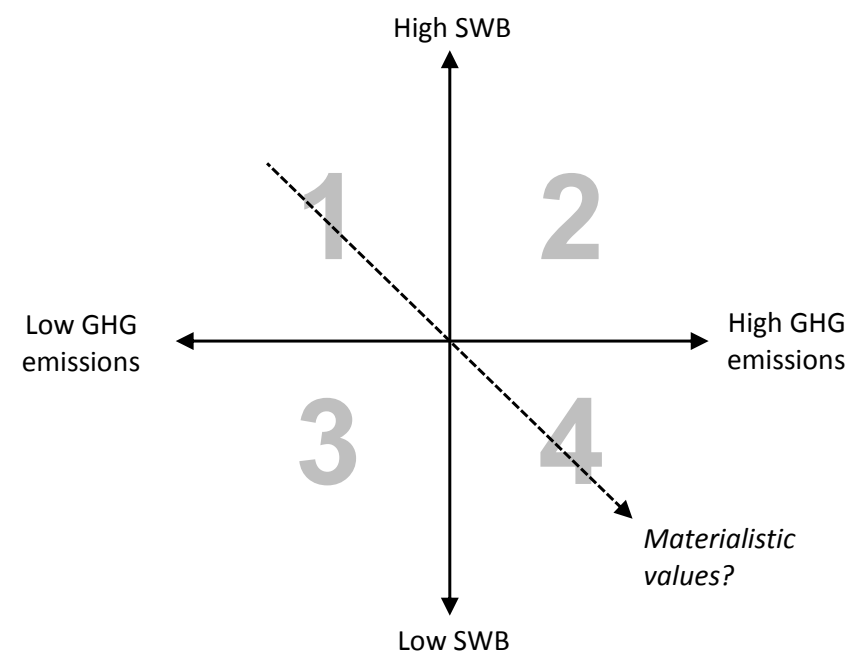

Figure 2: Schematic figure of the GHG/SWB sub-samples

The respondents are divided into four sub-samples using median splits on SWB and GHG respectively. Given the hypothesized effect of materialistic values on SWB and GHG emissions, we would expect the difference between groups 1 and 4 to be the largest.

A one-way ANOVA with a Tukey post-hoc test was conducted in order to compare our four sub-samples. Table 5 below displays the mean values for each sub-sample, where the largest significant difference among the sub-samples is marked in bold characters.

Table 5: ANOVA table on the SWB-GHG matrix The table depicts results from an ANOVA with a Tukey post-hoc test. The two variables marked in bold in each row indicate the strongest significant $(\mathrm{p}<0.001)$ mean difference for that variable.

\begin{tabular}{|c|c|c|c|c|c|c|c|c|c|c|}
\hline \multirow[t]{3}{*}{ Variables: } & \multirow{2}{*}{\multicolumn{2}{|c|}{$\begin{array}{c}1 \\
\text { H-SWB/L-GHG }\end{array}$}} & \multirow{2}{*}{\multicolumn{2}{|c|}{$\begin{array}{c}2 \\
\text { H-SWB/H-GHG }\end{array}$}} & \multirow{2}{*}{\multicolumn{2}{|c|}{$\begin{array}{c}3 \\
\text { L-SWB/L-GHG }\end{array}$}} & \multirow{2}{*}{\multicolumn{2}{|c|}{$\begin{array}{c}4 \\
\text { L-SWB/H-GHG }\end{array}$}} & \multicolumn{2}{|c|}{ Average } \\
\hline & & & & & & & & & \multirow[t]{2}{*}{ Mean } & \multirow[t]{2}{*}{$\mathrm{N}$. } \\
\hline & Mean & S.D. & Mear & S.D. & Mean & S.D. & Mear & S.D. & & \\
\hline $\begin{array}{l}\text { Materialistic } \\
\text { Values (0-10) }\end{array}$ & 2.03 & (1.77) & 2.48 & $(1.70)$ & 2.54 & $(1.84)$ & 2.86 & (1.83) & 2.49 & 954 \\
\hline $\begin{array}{l}\text { Time pressure } \\
(0-10)\end{array}$ & 4.05 & $(2.26)$ & 4.24 & $(2.21)$ & 4.92 & $(2.27)$ & 5.36 & $(2.08)$ & 4.65 & 951 \\
\hline $\begin{array}{l}\text { Overtime } \\
\text { (>40h/week) }\end{array}$ & .20 & $(.40)$ & .28 & $(.45)$ & .17 & $(.37)$ & .32 & $(.47)$ & .24 & 950 \\
\hline $\begin{array}{l}\text { Commute by car } \\
\text { (1-5 times/week) }\end{array}$ & 4.6 & (2) & 5.1 & (1.6) & 4.0 & (2.1) & 5.0 & (1.6) & 4.7 & 628 \\
\hline $\begin{array}{l}\text { Net income per } \\
\text { adult ( } \mathrm{t} \text { SEK) }\end{array}$ & 177 & (64) & 245 & (77) & 162 & (67) & 235 & (74) & 205 & 959 \\
\hline Education (1-8) & 4.67 & (1.84) & 5.30 & $(1.70)$ & 4.71 & $(1.83)$ & 5.33 & $(1.67)$ & 5.01 & 964 \\
\hline Children (\%) & 0.25 & $(0.44)$ & 0.46 & $(0.50)$ & 0.30 & $(0.46)$ & 0.42 & $(0.50)$ & 0.36 & 971 \\
\hline Male (\%) & 0.44 & $(0.50)$ & 0.44 & $(0.50)$ & 0.44 & $(0.50)$ & 0.49 & $(0.50)$ & 0.45 & 969 \\
\hline Age (20-66) & 47 & (14) & 47 & (12) & 44 & (14) & 46 & (11) & 46 & 971 \\
\hline Average $S W B$ : & \multicolumn{2}{|c|}{8.9} & \multicolumn{2}{|c|}{8.8} & \multicolumn{2}{|c|}{6.0} & \multicolumn{2}{|c|}{6.3} & \multicolumn{2}{|c|}{7.6} \\
\hline Average $G H G$ : & \multicolumn{2}{|c|}{6.0} & \multicolumn{2}{|c|}{10.6} & \multicolumn{2}{|c|}{5.7} & \multicolumn{2}{|c|}{10.7} & \multicolumn{2}{|c|}{8.3} \\
\hline
\end{tabular}


The results show that the difference in materialistic values between sub-samples 1 and 4 is significant $F(3,950)=7.51, p=.001$. The fact that the difference between subsamples 1 and 4 is the largest among the groups indicates that materialistic values do indeed affect both SWB and GHG emissions.

For "Time pressure," we also find the largest difference between groups 1 and 4 ( $F$ (3, $947)=16.8, p=.001$ ), which could indicate a double dividend, but it seems more likely that the difference is mainly manifested in the SWB dimension, as sub-samples 1, 2 and 3, 4 form homogenous subsets at $p<.05$ using the Tukey multiple comparison procedure. The difference in time-pressure can also be explained by the difference in household composition, since "being a parent" is more common in in sub-sample 4 than in sub-sample 1. When comparing the means for "Overtime" in table 5, we see that there is a significant difference in overtime work between sub-samples 3 and 4 , as $F(3,946)=6.82, p=.001$. But the Tukey test of homogenous subsets, groups subsamples 3,1 and 2, 4, which supports the more general conclusion that overtime work is primarily important to the GHG dimension, while not necessarily so for the SWB dimension. For "Commuting by car," the largest significant difference between the sub-samples is seen between samples 2 and $3, F(3,624)=11.86, p=.001$; this result does not support the hypothesized double dividend of reduced car commuting (we also tested for commuting-time and this result was similar but weaker).

\section{Discussion}

The analyses carried out in the previous sections have aimed to develop the understanding of the relationship between an individual's GHG emissions and SWB. The lack of connection between GHG emissions and SWB, both in general and for specific GHG intensive activities, adds further evidence to the view that consumption is not very important to SWB once the individual reaches a certain welfare level. In line with previous research, our analysis shows that health, work, and social relations explained almost 40 percent of the variation in the sample while amount of driving for non-work reasons, size of residence, and share of red meat in diet did not affect respondents SWB at all. Seen in this light, the results of the third analysis should not come as a surprise, as the materialist focus on acquisition and wealth seems wholly misdirected as a means to maximize SWB. 
However, our GHG-intensive behaviors are rather rough representations of specific consumer lifestyle practices with distinct meanings. Therefore, our analysis does not rule out the existence of more specific GHG-intensive consumer practices that may be perceived to be meaningful or in other ways contribute to a better life. As noted in section 3.3, the weak relationship between air travel and SWB could for example be interpreted to mean that some individuals have adopted a lifestyle where air travel fills a social purpose that in turn affects their SWB positively. Hence, although our main results point towards a low importance of GHG-intensive activities for the average individual's SWB, it does not necessarily mean that this lack of connection persists. New practices could emerge or socio-economical and physical structures could change, so that social interactions, job opportunities or health issues rely more heavily on GHG intensive activities.

A better understanding of how GHG-relevant practices evolve, what drives them, and how they are established may enable policymaking that counteracts some developments and facilitates the emergence of others. Such future research needs to identify specific consumer practices, analyze them in relation to other practices, estimate the related GHG emissions, and follow their evolution among different social-groups over time. This is a challenging task, but we believe it could be equally rewarding.

Three limitations should be kept in mind when considering our results. First, as this analysis is based on cross-sectional data, it is not possible to comment on the actual dynamic effect on SWB of reducing GHG emissions for the average individual. As pointed out by Kahneman (1999), even if actions and behaviors have become habitual and hence hedonically neutral to us, this does not mean that ceasing them would not affect our subjective well-being. However, given the weak correlation between GHG emissions and SWB, a long-term development towards decreased or curbed growth in private consumption in rich countries could be hypothesized not to affect SWB. Having social relationships, good health and being employed are important factors and a climate policy that does not affect these aspects of life negatively, or that even affect them positively (double dividends), is what is important in terms of our wellbeing (see FitzRoy et al. 2012 for a review of how climate change policies could act to improve SWB).

Second, the choice of subjective quality of life indicators has implications for the output of our analysis. Unlike objective quality of life indicators, subjective well- 
being is not a direct consequence of an individual's circumstances, but also depends on aspiration level, adaptation, comparisons with others, personal values, and so on (Wilson 1967). Increases in income and hence consumption and GHG emissions may have a positive effect on objective indicators, while the effect on SWB is more ambiguous. In this study we have chosen to employ SWB since we believe its benefits outweigh its drawbacks for analyses of individuals living in affluent countries. Once primary needs are fulfilled, the importance of values and relational factors to our quality of life increases (Kahneman et al. 2006). The other main advantage of SWB is that it is based on an aggregate of various individual assessments of what is important in life, rather than a priori judgments about what should be important (OECD 2013). However, some technical and methodological issues remain to be dealt with (Brief et al 1993; Kahneman et al. 2010; Diener et al. 2009).

Third, our results are probably restricted to other affluent welfare states. The comparatively ambitious redistribution systems found in countries in Western Europe probably moderate the importance of income to SWB for low-income individuals and households, compared to other developed countries. Clearly, poor people in both developing and developed countries that lack social security systems would benefit from increased levels of consumption. The fact that our sample population differed somewhat from the general population in terms of income and education should also merit some caution as to the generalizability of these results.

\section{Conclusions}

In this paper we have investigated the link between greenhouse gas (GHG) emissions and subjective well-being (SWB) among individuals in Sweden. To our knowledge this is the first explicit examination of this relationship that analyze individual differences covering GHG emissions from all relevant consumption areas. The initial bivariate analysis indicates a weak positive relationship between GHG emissions and SWB. In a second step we analyzed if certain GHG intensive activities and living conditions, such as size of residence, non-work driving distance, air travel and the fraction of meals that include red meat, could explain variations in SWB. The multivariate analysis shows that when "controlling" for factors such as having good health, a job, a partner and other relations, factors that have previously been shown to affect SWB, the weak relationship found between air travel and SWB disappears. It therefore seems as if a living a low carbon life does not prevent someone from leading 
a good life. A third aim of the study was to investigate potential double dividends by analyzing individuals with low GHG emissions and high SWB to see how they differ from other respondents. We examined whether these respondents differed in worklife-balance, commuting, or material values, and our analysis provides tentative support for the idea that materialist dispositions affect SWB negatively, while GHG emissions seem to increase, which is also in line with the results above. 


\section{References}

Abdallah et al, 2009. The Happy Planet Index 2.0: Why good lives don't have to cost the Earth. New Economics Foundation.

Alexander, S. and S. Ussher (2012). "The Voluntary Simplicity Movement: A multinational survey analysis in theoretical context." Journal of Consumer Culture 12(1): 66-86.

Argyle, Michael (1999), 'Causes and correlates of happiness', in Daniel Kahneman, Ed Diener, and Norbert Schwarz (eds.), Well-being: the foundations of hedonic psychology (New York: Russell Sage Foundation), xii, 593 p.

Azar, C. and Johansson, D. 2012, "Valuing the non-CO2 impacts of aviation" Climatic Change, vol. 111 pp. 559-579.

Bauman, Z. (2011). Consuming Life, Polity.

Brief, A.; Butcher, A.; George, J.; Link, K. (1993) "Integrating bottom-up and topdown theories of subjective well-being: The case of health" Journal of Personality and Social Psychology, Vol 64(4), 646-653.

Brown, Kirk Warren and Kasser, Tim (2005), 'Are psychological and ecological wellbeing compatible? The role of values, mindfulness, and lifestyle', Social Indicators Research, 74, 349-68.

Brülde, B. (2007). Happiness and the good life. Introduction and conceptual framework. Journal of Happiness Studies, 8(1), 1-14.

Brülde, B., and Fors, F., (2013) Är lyckan grön? Ekonomisk Debatt. Vol. 41. No 2.

Bryngelsson, D., Hedenus, F., Larsson, J., (2013) Scenarier för klimatpåverkan från matkonsumtionen 2050. Underlagsrapport till Göteborgs kommuns klimatstrategiarbete Chalmers, Avdelningen för Fysisk Resursteori, Report nr. 2013:3

Csikszentmihalyi, I. S. (Ed.). (1992), Optimal experience: Psychological studies of flow in consciousness. Cambridge University Press.

Diener, E., Suh, E. M., Lucas, R. E., \& Smith, H. L. (1999). Subjective well-being: Three decades of progress. Psychological bulletin, 125(2), 276.

Diener, E., Wirtz, D., Tov, W., Kim-Prieto, C., Choi. D., Oishi, S., \& Biswas-Diener, R. (2009). New measures of well-being: Flourishing and positive and negative feelings. Social Indicators Research, 39, 247-266.

Dolan, P,. et al. (2006), 'Final report for Defra. Research on the relationship between well-being and sustainable development'.

Easterlin, R. A. (2003). Explaining happiness. Proceedings of the National Academy of Sciences, 100(19), 11176-11183.

European Council, 2005. Presidency conclusions, 7619/1//05 REV 1, Council of the European Union, Brussels 22 an 23 March 2005.

FitzRoy, F., Franz-Vasdeki, J., \& Papyrakis, E. (2012). Climate Change Policy and Subjective Well-Being. Environmental Policy and Governance, 22(3), 205-216.

Fors, F \& Brülde, B (2011) "Välbefinnande och livstillfredsställelse i dagens Sverige" in Sören Holmberg, Lennart Weibull \& Henrik Oscarsson (red) Lycksalighetens ö. Göteborg: SOM-institutet, Göteborgs universitet. 
Hansson, E., Mattisson, K., Björk, J., Östergren, P. O., \& Jakobsson, K. (2011). Relationship between commuting and health outcomes in a cross-sectional population survey in southern Sweden. BMC public health, 11(1), 834.

Hurst, M., Dittmar, H., Bond, R., \& Kasser, T. (2013). The relationship between materialistic values and environmental attitudes and behaviors: A metaanalysis. Journal of Environmental Psychology.

Inglehart, Ronald, et al. (2008), 'Development, Freedom, and Rising Happiness: A Global Perspective, Perspectives on Psychological Science, 3 (4), 264-85.

Jackson, T. (2005). Live Better by Consuming Less?: is there a "double dividend" in sustainable consumption?. Journal of Industrial Ecology, 9(1-2), 19-36. Chicago

Jackson, Tim (2009), Prosperity without growth: economics for a finite planet (London ; Sterling, VA: Earthscan), 264 p.

Kahneman, D., \& Deaton, A. (2010). High income improves evaluation of life but not emotional well-being. Proceedings of the National Academy of Sciences, 107(38), 16489-16493.

Kahneman, Daniel (1999), 'Objective happiness', in Daniel Kahneman, Ed Diener, and Norbert Schwarz (eds.), Well-being: the foundations of hedonic psychology (New York: Russell Sage Foundation), xii, 593 p.

Kahneman, Daniel, et al. (2006) "Would you be happier if you were richer? A focusing illusion." Science 312. 5782: 908-1910.

Karyd A., (2013) Fossilfri flygtrafik? Underlagsrapport till utredningen om fossiloberoende ordonsflotta, N 2012:05.

Kerkhof, A. C., Nonhebel, S., and Moll, H.C. (2009). Relating the environmental impact of consumption to household expenditures: An input-output analysis. Ecological Economics 68(4): 1160-1170.

Killingsworth, Matthew A. and Gilbert, Daniel T. (2010), 'A Wandering Mind Is an Unhappy Mind', Science, Vol. 330 (6006), 932.

Knight, K. W., Rosa, E. A., \& Schor, J. B. (2013). Could working less reduce pressures on the environment? A cross-national panel analysis of OECD countries, 1970-2007. Global Environmental Change.

Larsson, J. (2012). "Studier i tidsmässig välfärd - med fokus på tidsstrategier och tidspolitik för småbarnsfamiljer" Doctoral thesis at the Department of Sociology, University of Gothenburg.

Lenzen, M., \& Cummins, R. A. (2013). Happiness versus the Environment-A Case Study of Australian Lifestyles. Challenges, 4(1), 56-74.

Lenzen, M., Wier, M., Cohen, C., Hayami, H., Pachauri, S., and Schaeffer, R. (2006). A comparative multivariate analysis of household energy requirements in Australia, Brazil, Denmark, India and Japan. Energy 31(2-3): 181-207.

Markowitz, E. M., \& Bowerman, T. (2012). How much is enough? Examining the public's beliefs about consumption. Analyses of Social Issues and Public Policy, 12(1), 167-189.

Mazur, A. (2011). Does increasing energy or electricity consumption improve quality of life in industrial nations?. Energy Policy, 39(5), 2568-2572.

Meinshausen, M., Meinshausen, N., Hare, W., Raper, S. C., Frieler, K., Knutti, R., \& Allen, M. R. (2009). "Greenhouse-gas emission targets for limiting global warming to 2 C”. Nature, 458(7242), 1158-1162. 
Miller, D. (1998). A theory of shopping. Cornell University Press.

Mutrie, N., Faulkner, G., (2004). 'Physical activity: Positive psychology in motion', in P. Alex Linley and Stephen Joseph (eds.), Positive psychology in practice (Hoboken, N.J.: Wiley):46-64.

Nässén, J., (2014) "Determinants of greenhouse gas emissions from Swedish private consumption: Time-series and cross-sectional analyses" Energy In press, availible online: http://www.sciencedirect.com/science/article/pii/S0360544214000267

Nässén, J., Larsson J., (2014) Would shorter working time reduce greenhouse gas emissions?: An analysis of time use and consumption in Swedish households, Environment and Planning C: Government and Policy, In press.

Nawijn, J., \& Peeters, P. M. (2010). Travelling 'green': is tourists' happiness at stake?. Current Issues in Tourism, 13(4), 381-392.

OECD (2013) Guidelines on Measuring Subjective Well-being. Link: http://www.oecd.org/statistics/Pages\%20from\%20Guidelines\%20on\%20Measurin g\%20Subjective\%20Well-being-Chapter-4.pdf

Olsson, L. E., Gärling, T., Ettema, D., Friman, M., \& Fujii, S. (2013). Happiness and satisfaction with work commute. Social indicators research, 111(1), 255-263.

Patterson, J., Alexander, M., and Gurr, A. (2011). "Preparing for a Life Cycle CO2 Measure" Low Carbon Vehicle Partnership: www.lowcvp.org.uk/assets/reports/RD11_124801_5\%20-\%20LowCVP\%20$\% 20$ Life $\% 20$ Cycle $\% 20 \mathrm{CO} \% 20$ Measure\%20-\%20Final\%20Report.pdf

Richins, Marsha L. and Dawson, Scott (1992), 'A Consumer Values Orientation for Materialism and Its Measurement: Scale Development and Validation', Journal of Consumer Research:9 (3), 303-16.

Richins, Marsha L., (2004), “The Material Values Scale: Measurement Properties and Development of a Short Form Journal of Consumer Research Vol. 31, No. 1, pp. 209-219

Rogelj, J., W. Hare, J. Lowe, D. P. Van Vuuren, K. Riahi, B. Matthews, T. Hanaoka, K. Jiang, and M. Meinshausen. (2011) "Emission pathways consistent with a $2^{\circ} \mathrm{C}$ global temperature limit" Nature Climate Change 1(8): 413-418.

Röös, E. 2012. Mat-klimat-listan. SLU, Uppsala.

Ryan, Lisa and Dziurawiec, Suzanne (2001), 'Materialism and Its Relationship to Life Satisfaction', Social Indicators Research, 55 (2):85-97.

Schor, J. (1998). The Overspent American. Why we Want what we don't Need. New York, Basic Books.

Sekulova, F., \& van den Bergh, J. C. (2013). Climate change, income and happiness: An empirical study for Barcelona. Global Environmental Change, 23(6), 14671475.

SEPA (2008) Konsumtionens klimatpåverkan Report 5903. Internet resource: http://www.naturvardsverket.se/Documents/publikationer/978-91-620-5903-3.pdf

SEPA 2013a statistics database available online: http://www.naturvardsverket.se/klimat2012

SEPA 2013b Statistics database available online: http://www.naturvardsverket.se/Samar-miljon/Statistik-A-O/Vaxthusgaser--utslapp-av-svensk-konsumtion/

Shove, E. (2004). "Efficiency and Consumption: Technology and Practice." Energy \& Environment 15(6): 1053-1065. 
SIKA (2007) RES 2005-2006 The National Swedish Travel Survey. Statistik 2007:19.

SOM (2012) National survey on Society Opinion Media. http://www.som.gu.se/som_institute/-surveys/national-som/

Statistics Sweden (2013) Statistics database available online: http://www.scb.se/Pages/SSD/SSD_TreeView 340478.aspx

Steel, Piers; Schmidt, Joseph \& Shultz, Jonas (2008). "Refining the relationship between personality and Subjective well-being". Psychological Bulletin 134 (1): $138-161$.

Stutzer, Alois and Frey, Bruno S. (2008), 'Stress that Doesn't Pay: The Commuting Paradox', Scandinavian Journal of Economics 10 (2), 339-66.

Swedish department of Agriculture (2013), statistics database available online: http://www.jordbruksverket.se/etjanster/etjanster/statistikdatabas.4.6a459c1812061 7aa58a80001011.html

Tjernström, E., Tietenberg, T., (2008) "Do differences in attitudes explain differences in national climate change policies?" Ecological Economics 65, 315-324.

VTT, (2009) Internet resource: http://lipasto.vtt.fi/yksikkopaastot/henkiloliikennee/ilmaliikennee/ilmae.htm

Williams, G. C., et al. (2000), 'Extrinsic Life Goals and Health-Risk Behaviors in Adolescents1', Journal of Applied Social Psychology, 30 (8): 756-71.

Wilson, J., Tyedmers, P., \& Spinney, J. E. (2013). An Exploration of the Relationship between Socioeconomic and Well-Being Variables and Household Greenhouse Gas Emissions. Journal of Industrial Ecology, 17(6), 880-891.

Wilson, W. R. (1967). Correlates of avowed happiness. Psychological bulletin, 67(4), 294.

Zidansek A, 2007. Sustainable development and happiness in nations, Energy, 32, 891-97.

Åkerman, Jonas, et al. (2007), 'Tvågradersmålet i sikte? Scenarier för det svenska energi- och transportsystemet till år 2050', Stockholm Naturvårdsverket. 